\title{
PERLINDUNGAN HUKUM TERHADAP PEREMPUAN PEKERJA PEMBUAT ATAP DI DESA AMOKUNI KECAMATAN RANOMEETO BARAT KABUPATEN KONAWE SELATAN
}

\author{
Rima Anggriyani ${ }^{1}$; Muryanto Lanontji ${ }^{2}$ \\ Program Studi Ilmu Hukum, Fakultas Hukum Universitas Muhammadiyah Kendari \\ e-mail: rimaanggriyani@umkendari.ac.id, ”muryanto@umkendari.ac.id
}

\begin{abstract}
ABSTRAK: Tujuan penelitian ini untuk mengetahui bagaimana perlindungan hukum bisnis terhadap perempuan pekerja pembuat atap di Desa Amokuni Kecamatan Ranomeeto Barat Kabupaten Konawe Selatan dan untuk mengetahui faktor-faktor yang mempengaruhi perlindungan hukum terhadap perempuan pekerja atap. Metode penelitian ini berupa penelitian normatif empiris, penelitian dengan melihat peristiwa yang terjadi ditengah masyarakat berdasarkan peraturan perundangundangan sehubungan dengan tinjauan yuridis terhadap kesejahteraan perempuan pekerja pembuat atap di Desa Amokuni Kecamatan Ranomeeto Barat Kabupaten Konawe Selatan. Perlindungan hukum bisnis terhadap perempuan pekerja pembuat atap di Desa Amokuni Kecamatan Ranomeeto Barat Kabupaten Konawe Selatan bukan hanya sekedar dari hubungan antara perempuan pembuat atap dengan pembeli atap dalam sebuah perjanjian jual beli, tetapi peran pemerintah harusnya dapat turun langsung melalui aparat pemerintah desa dengan melakukan perlindungan dengan cara membuat kelompok-kelompok tani/usaha, sehingga haknya dapat maksimal diberikan perlindungan oleh hukum. Apakah itu mengenai Kesehatan dan Keselamatan Kerja (K3), asuransi sosial, maupun keberlangsungan dari usaha serta kearifan lokal dapat tumbuh dan terjaga di desa tersebut. Faktor-faktor yang mempengaruhi perlindungan hukum terhadap perempuan pekerja atap di Desa Amokuni Kecamatan Ranomeeto Barat Kabupaten Konawe Selatan adalah kurangnya kesadaran perempuan tentang pentingnya Kesehatan dan Keselamatan Kerja (K3) dalam membuat atap, tidak adanya pelatihan yang diberikan pemerintah tentang usaha untuk membentuk kelompok pekerja/koperasi kepada perempuan pembuat atap serta daya saing kualitas dan kuantitas tidak mencirikan kearifan lokal dari Desa Amokuni. Rekomendasi yang peneliti berikan berupa: 1).Pemerintah daerah melalui kepala desa Amokuni, dapat mengakomodir perempuan pembuat atap untuk dibentuk kelompok tani/usaha yang berbadan hukum. 2).Perempuan pembuat atap dapat meningkatkan kualitas dan kuantitas dalam menghasilkan lembaran atap sehingga kekhasan daerah dan kearifan lokalnya dapat terjaga.
\end{abstract}

Kata Kunci: perlindungan hukum; perempuan, pembuat atap.

Abstract: The purpose of this research is to find out how business law protection of women roof workers in Amokuni Village, Ranomeeto Barat District, Konawe Selatan Regency and to determine the factors that influence legal protection of women roof workers. This research method is in the form of empirical normative research, research by looking at events that occur in the community based on statutory regulations in connection with a juridical review of the welfare of women roofing workers in Amokuni 
Village, Ranomeeto Barat District, South Konawe Regency. The protection of business law for women roofing workers in Amokuni Village, Ranomeeto Barat Subdistrict, Konawe Selatan Regency is not just a relationship between women who make roofs and buyers of roofs in a sale and purchase agreement, but the role of the government should be able to go down directly through village government officials by providing protection with how to create farmer / business groups, so that their rights can be maximally protected by law. Whether it is about Occupational Health and Safety (K3), social insurance, as well as business sustainability and local wisdom can grow and be maintained in the village. The factors that influence the legal protection of women roof workers in Amokuni Village, Ranomeeto Barat District, Konawe Selatan Regency are the lack of awareness of women about the importance of Occupational Health and Safety (K3) in making roofs, the absence of training provided by the government on efforts to form worker groups / cooperatives to women who make roofs and the competitiveness of quality and quantity do not characterize the local wisdom of Amokuni Village. The recommendations that the researchers gave were: 1) The regional government, through the head of Amokuni village, could accommodate women who made roofs to form farmer / business groups that were legal entities. 2) Women who make roofs can improve the quality and quantity in producing roofing sheets so that regional distinctiveness and local wisdom can be maintained.

Keywords: legal protection; women, roof makers.

\section{PENDAHULUAN}

Salah satu syarat untuk keberhasilan pembangunan nasional adalah kualitas manusia Indonesia yang menentukan berhasil tidaknya usaha untuk memenuhi tahap tinggal landas. Peningkatan kualitas manusia tidak mungkin tercapai tanpa memberikan jaminan hidup, sebaliknya jaminan hidup tidak dapat tercapai apabila manusia tidak mempunyai pekerjaan, dimana dari hasil pekerjaan itu dapat diperoleh imbalan jasa untuk membiayai dirinya dan keluarganya.

Peranan hukum di dalam pergaulan hidup adalah sebagai sesuatu yang melindungi, memberi rasa aman, tentram dan tertib untuk mencapai kedamaian dan keadilan setiap orang. Hukum seyogyanya memberikan keadilan, karena itulah tujuan dari hukum.

Menurut Walter A.Firedlander (1961) kesejahteraan sosial adalah sistem yang terorganisir dari pelayanan-pelayanan sosial dan lembaga-lembaga yang bertujuan untuk membantu individu dan kelompok untuk mencapai standar hidup dan kesehatan yang memuaskan dan relasi-relasi pribadi dan sosial yang memungkinkan mereka mengembangkan kemampuannya sepenuh mungkin dan meningkatkan kesejahteraannya secara selaras dengan kebutuhan keluarga dan masyarakat.

Menurut Athur Dunham (1965) kesejahteraan sosial didefinisikan sebagai kegiatan-kegiatan yang terorganisasi dengan tujuan meningkatkan kesejahteraan dari segi sosial melalui pemberian bantuan kepada orang untuk memenuhi kebutuhankebutuhan di dalam beberapa bidang seperti kehidupan keluarga dan anak, kesehatan, penyesuaian sosial, waktu senggang, standa-standar kehidupan dan hubunganhubungan sosial. Pelayanan kesejahteraan sosial memberi perhatian utama terhadap individu-individu, kelompok-kelompok, komunitas-komunitas dan kesatuan-kesatuan 
penduduk yang lebih luas; pelayanan ini mencakup pemeliharaan atau perawatan, penyembuhan dan pencegahan.

Harold L.Wilensky (1965) mendefinisikan kesejahteraan sosial adalah suatu system yang terorganisir dari usaha-usaha pelayanan sosial dan lembaga-lembaga sosial, untuk membantu individu-individu dan kelompok dalam mencapai tingkat hidup serta kesehatan yang memuaskan. Maksudnya agar individu dan relasi-relasi sosialnya memperoleh kesempatan yang seluas-luasnya untuk mengembangkan kemampuankemampuannya serta meningkatkan atau menyempurnakan kesejahteraan sebagai manusia sesuai dengan kebutuhan masyarakat.

Alfred J.Khan (1973) menyatakan bahwa kesejahteraan sosial terdiri dari program-program yang tersedia selain yang tercakup dalam kriteria pasar untuk menjamin suatu tindakan kebutuhan dasar seperti kesehatan, pendidikan kesejahteraan, dengan tujuan meningkatkan derajat kehidupan komunal dan berfungsi individual, agar dapat mudah menggunakan pelayanan-pelayanan maupun lembagalembaga yang ada pada umumnya serta membantu mereka yang mengalami kesulitan dan dalam pemenuhan kebutuhan mereka.

Lalu menurut Zastrow (2000) kesejahteraan sosial adalah sebuah sistem yang meliputi program dan pelayanan yang membantu orang agar dapat memenuhi kebutuhan sosial, ekonomi, pendidikan dan kesehatan yang sangat mendasar untuk memelihara masyarakat. Sebagaimana batasan PBB, kesejahteraan sosial adalah kegiatan-kegiatan yang terorganisasi yang bertujuan untuk membantu individu atau masyarakat guna memenuhi kebutuhan-kebutuhan dasarnya dan meningkatkan kesejahteraan selaras dengan kepentingan keluarga dan masyarakat.

Berdasarkan Undang-Undang Republik Indonesia Nomor 11 tahun 2009, kesejahteraan sosial adalah kondisi terpenuhinya kebutuhan material, spiritual, dan sosial warga Negara agar dapat hidup layak dan mampu mengembangkan diri, sehingga dapat melaksanakan fungsi sosialnya, dan penyelenggaraan kesejahteraan sosial adalah upaya terarah, terpadu, dan berkelanjutan yang dilakukan pemerintah, pemerintah daerah, dan masyarakat dalam bentuk pelayanan sosial guna memenuhi kebutuhan dasar setiap warga Negara, yang meliputi rehabilitasi sosial, jaminan sosial, pemberdayaan sosial dan perlindungan sosial. Dimana dalam penyelenggaraannya dilakukan atas dasar kesetiakawanan, keadilan, kemanfaatan, keterpaduan, kemitraan, keterbukaan, akuntabilitas, partisipasi, profesionalitas dan keberlanjutan.

Berdasarkan pengamatan peneliti di Desa Amokuni Kecamatan Ranomeeto Barat Kabupaten Konawe Selatan terdapat ibu-ibu rumah tangga yang bekerja sebagai pembuat atap. Pembuat atap tersebut secara turun temurun telah dilakukan dari sejak dahulu hingga turun dari generasi ke generasi, hal ini bukan hanya untuk memenuhi kebutuhan hidupnya dan keluarga. Akan tetapi, sudah menjadi rutinitas wajib yang dilakukan. Bahwa kenyataan yang demikian dilakukan karena ketersediaan sumber daya alam yakni bahan baku yang ada walaupun juga jika tidak memiliki bahan baku berarti membeli kepada tetangga rumah di desa tersebut sehingga harga jual pun terhadap lembaran atap yang dibuat masih tetap ada sampai sekarang. Jika dikaji dalam konsep hukum bisnis, dapat dibuatkan kelompok usaha, apakah bentuknya berbadan hukum ataupun tidak berbadan hukum sehingga dapat meningkatkan harga dan kualitas dari atap yang dibuat tersebut. 
Tujuan penelitian ini yaitu untuk mengetahui bagaimana perlindungan hukum bisnis terhadap perempuan pekerja pembuat atap di Desa Amokuni Kecamatan Ranomeeto Barat Kabupaten Konawe Selatan dan untuk mengetahui faktor-faktor yang mempengaruhi perlindungan hukum terhadap perempuan pekerja atap.

\section{METODE PENELITIAN}

Jenis Penelitian yang digunakan dalam penelitian ini adalah normatif empiris. Jenis penelitian normatif empiris adalah penelitian dengan melihat peristiwa yang terjadi ditengah masyarakat berdasarkan peraturan perundang-undangan sehubungan dengan tinjauan yuridis terhadap kesejahteraan perempuan pekerja pembuat atap di Desa Amokuni Kecamatan Ranomeeto Barat Kabupaten Konawe Selatan.

Sumber data penelitian ini berupa: data primer yaitu diperoleh dengan cara mengumpulkan sejumlah keterangan atau fakta melalui wawancara secara terarah dan sistematis dengan pihak yang dipandang mengetahui serta memahami tentang objek yang diteliti yaitu yang diperoleh dari lokasi penelitian di Desa Amokuni Kecamatan Ranomeeto Barat Kabupaten Konawe Selatan dan data sekunder yaitu Merupakan keterangan atau fakta yang diperoleh tidak secara langsung, tapi diperoleh melalui studi pustaka, literatur, peraturan perundang-undangan, karya ilmiah dan sumber tertulis lainnya yang berkaitan dengan masalah yang diteliti oleh peneliti.

Data yang diperoleh baik dari studi lapangan maupun kepustakaan diteliti dengan metode analisa deskriptif kualitatif yaitu data yang diperoleh akan digambarkan sesuai dengan keadaan yang sebenarnya, apa yang dikatakan responden baik secara lisan maupun tulisan, yang akan diteliti dan dipelajari sebagai satu kesatuan yang utuh, untuk kemudian dilakukan analisis guna menjawab yang ada dalam penelitian ini.

\section{HASIL PENELITIAN DAN PEMBAHASAN}

Rumah tangga petani sebagai sumber tenaga kerja, akan bekerja untuk memperoleh upah dalam kegiatan usahatani milik keluarga. Namun dengan adanya peluang untuk bekerja di luar kegiatan usahatani mendorong petani membuat keputusan untuk mengalikasikan tenaga kerja yang tersedia menjadi lebih efisien, sehingga dapat diasumsikan bahwa dengan tingkat pendapatan usahatani yang rendah, rumah tangga petani akan memaksimalkan pendapatannya dengan jalan mengkombinasikan kegiatannya (Saad, 2006).

Menurut Winardi (2005), fenomena pencaharian pendapatan tambahan rumah tangga sudah sangat lazim terjadi. Hal ini menandai adanya keragaman dalam sumber pendapatan rumah tangga. Pendapatan rumah tangga petani berasal dari sumber yang selalu berubah sesuai dengan musim, pasar tenaga kerja, dan waktu luang setiap harinya yang dimiliki anggota keluarga petani. Pembagian pekerjaan relatif lentur diantara anggota keluarga. Hal ini menyebabkan munculnya pengambilan keputusan untuk mencurahkan waktu kerja lebih banyak ke dalam kegiatan usahatani atau aktivitas kerja selain usahatani. Perilaku pencurahan waktu kerja petani sangat dipengaruhi oleh karakteristik rumah tangga petani yang tergambar dari umur dan pendidikan suami, istri, jumlah anggota dan tenaga kerja keluarga, jumlah anak sekolah dan balita, lama menetap serta pengalaman usahatani. 
Wanita memegang peran penting sebagai ibu rumah tangga dengan berbagai jenis pekerjaan dari yang berat sampai yang ringan, seperti mengatur rumah tangga, memasak, mencuci, mengasuh dan mendidik anak. Namun sejalan dengan perkembangan teknologi disektor pertanian, maka perempuan perlu meningkatkan pengetahuan, keterampilan sehingga dapat mengambil manfaat yang sebesar-besarnya dari segala jenis sumber daya yang ada disekitarnya berupa sumber daya alam maupun sumber daya manusia. Karena itu, kemajuan yang dicapai perempuan zaman sekarang dapat dijumpai pada banyak kaum hawa ini sebagai motor penggerak pembangunan dibidang pertanian, seperti kelompok tani, dalam kegiatan program peningkatan produksi pertanian, dalam kegiatan program peningkatan produksi pertanian, dalam kegiatan pasca panen produksi pertanian. Termasuk mengandung beban rumah tangga seperti mengambil air, mencari kayu bakar, memasak, menjual hasil panen, mendidik anak-anaknya, sebagai ibu rumah tangga dan mengabdi kepada suaminya (Nurmayasari, 2014).

Berdasarkan hasil wawancara tanggal 13 Maret 2017, peneliti dengan Kepala Desa Amokuni Kecamatan Ranomeeto Barat Kabupaten Konawe Selatan, mengatakan bahwa: Kaum perempuan (ibu rumah tangga) $80 \%$ di desa kami adalah pembuat atap, yang bahan bakunya berasal dari daun sagu dan bambu. Biasanya atap tersebut dinamakan atap rumbia. Sedangkan sisanya $20 \%$ adalah petani, pekebun, pedagang dan wiraswasta.

Hal yang sama dikatakan juga oleh ibu Hasdiana, warga dusun III Desa Amokuni mengatakan bahwa: Pekerjaan rutin saya setiap hari adalah membuat atap yang berasal dari daun sagu. Lumayan menambah kebutuhan dapur, biasanya sehari bisa dibuat 30 lembar atap, itupun tergantung bahan bakunya antara lain pengikatnya atap dan bambu. Kalau saya semua bahan baku tersebut berasal dari tanaman di kebun, baik itu pohon sagu, Bambu maupun pengikat untuk atap. Harga per lembarnya atap dijual Rp.3.000,- (tiga ribu rupiah) tergantung kualitas dan besarnya atap yang di buat. (Wawancara tanggal 13 Maret 2017). Penjelasan tersebut peneliti sajikan berupa gambar proses penebangan daun sagu, pengumpulan hingga proses pemotongan bambu yang dilakukan oleh salah satu ibu rumah tangga di desa tersebut, seperti tampak pada gambar 1 di bawah ini:

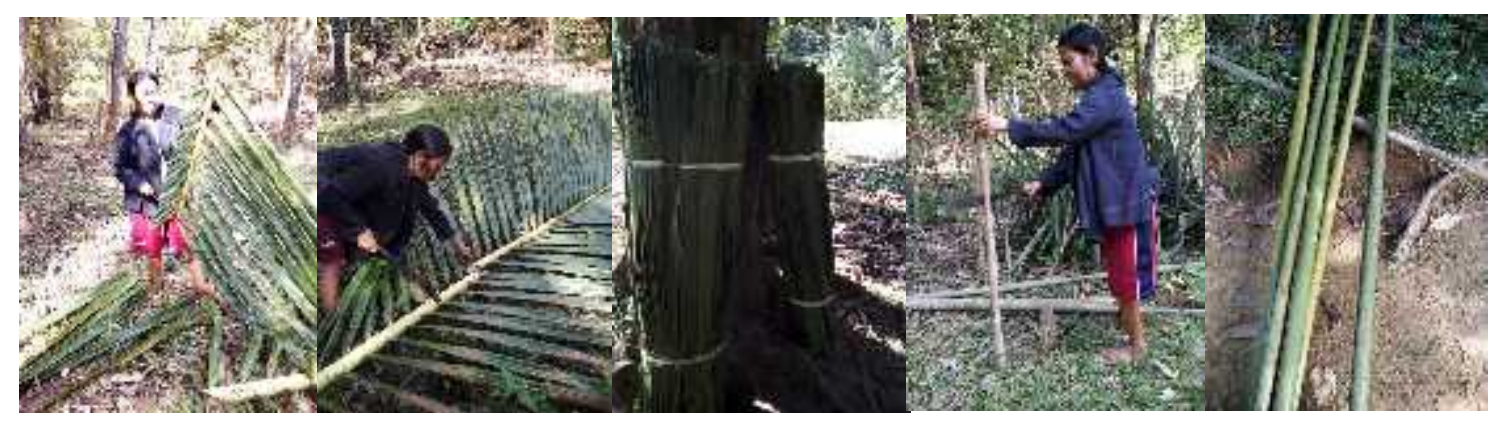

Gambar 1. Proses Penebangan Daun Sagu, Pengumpulan dan Pemotongan Bambu

Selanjutnya, berdasarkan hasil wawancara tanggal 14 Maret 2017 dengan Ibu Aswin warga dusun II, mengatakan bahwa: pembuatan atap dimulai dengan mengambil bahan baku, meliputi daun sagu, pengikat dan bambu. Untuk daun sagu dan pengikat 
adalah miliknya, sedangkan bambu dibeli dari kebun tetangga. Harga bambu 1 batang dijual seharga Rp.5.000,-(lima ribu rupiah), jika bambunya tua maka 1 batang bisa menghasilkan 500 lembar atap. Dalam sehari dapat dibuat 35-45 lembar atap. Harga perlembarnya di jual Rp.3.000,-(tiga ribu rupiah) yang dibeli salah seorang pengumpul yang merupakan warga dusun II Desa Amokuni. Penjelasan tersebut peneliti sajikan berupa gambar proses pembuatan atap daun sagu yang dilakukan oleh salah satu ibu rumah tangga di desa tersebut, seperti tampak pada gambar 2 di bawah ini:

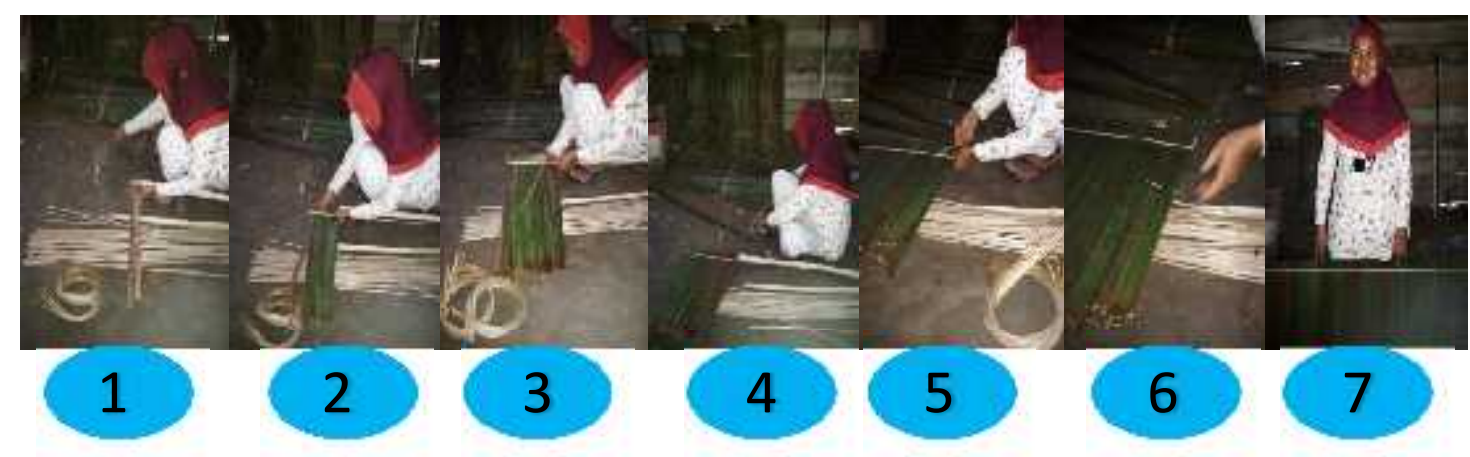

Gambar 2. Pembuatan Atap Daun Sagu

Selanjutnya, berdasarkan hasil wawancara tanggal 14 Maret 2017 dengan Ibu Weudi warga dusun I, mengatakan bahwa: Harga atap yang dijual perlembarnya Rp.3.000,-(tiga ribu rupiah), kualitasnya terjamin sampai 3 tahun dengan panjang 1 meter $40 \mathrm{~cm}$. atap yang dibuat seharinya sebanyak 35 lembar, dengan waktu pengerjaannya dimulai pukul 07.30 Wita sampai 17.00 wita.

Berbeda dengan Ibu Siti Mewa, berdasarkan hasil wawancara tanggal 14 Maret 2017, mengatakan bahwa: Pembuatan atap dilakukan pada pagi hari pukul 08.00 Wita setelah pekerjaan ibu rumah tangga selesai. Pekerjaan ini dilakukan dengan cara sistem kelompok dengan cara bantu membantu, misalkan 2 hari berturut-turut saya membantu tetangga membuat atap sebanyak 75 lembar, maka ketika hari ini dirumah saya membuat atap, maka tetangga yang saya bantu kemarin, membuat atap sebanyak 75 lembar. Hal tersebut dikarenakan bahan baku pembuatan atap berupa daun sagu, pengikat dan bambu serba dibeli, bukan seperti tetangga hasil dari kebunnya. Harga perlembarnya di jual Rp.3.000,-(tiga ribu rupiah) yang setiap minggunya pengumpul datang membeli. Penjelasan tersebut peneliti sajikan berupa gambar di bawah ini:

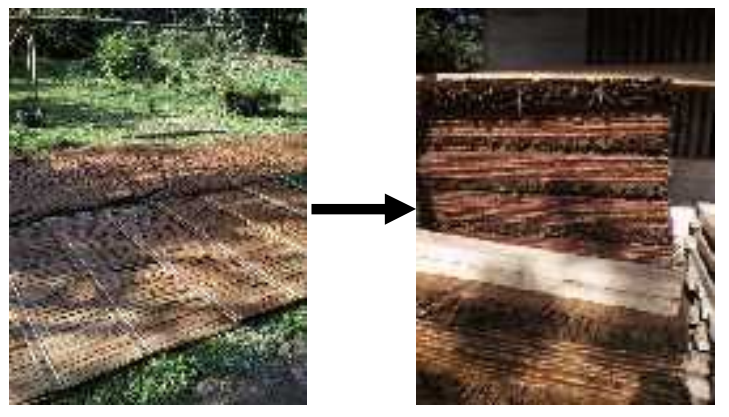

Gambar 3. Proses penjemuran dan penyusunan atap 
Dari hasil penelitian penulis, bahwa terhadap bahan baku pembuatan atap merupakan hasil kebun berupa daun sagu, pengikat dan bambu. Rata-rata perempuan pembuat atap dapat menghasilkan 25-45 lembar/hari. Dapat dijual dengan harga Rp.2.500 - Rp.3.000,- per lembarnya. Hal tersebut dapat dibedakan dengan kualitas dan kuantitasnya. Kualitasnya maksudnya adalah daun sagu dibedakan dari pohon sagu yang sudah tua (pohon sagu ditebang) dengan pohon sagu yang masih muda/belum ditebang. Jika dibuat dengan menggunakan daun pohon sagu yang sudah tua (pohon sagu yang ditebang) maka kualitas atap tersebut akan tahan lama dibandingkan dengan daun sagu yang masih muda hal ini tentu menentukan kuantitas harga dari lembaran atap yang dijual. Hal lain lagi adalah tingkat kerapatan lembaran daun sagu yang disusun/dianyam/dibuat, semakin rapat maka daya tahan atap semakin bagus karena tidak mudah rusak dan bocor. Kemudian telah dilakukan sistem gotong royong dalam melakukan pekerjaan pembuat atap dilakukan dengan membentuk kelompok perempuan per kelompok sebanyak 5-6 orang, dengan bantu membantu dapat mempercepat pembuatan atap tersebut.

\section{Perlindungan Hukum Bisnis Terhadap Perempuan Pekerja Pembuat Atap di Desa Amokuni Kecamatan Ranomeeto Barat Kabupaten Konawe Selatan}

Menurut Pierson, kata kesejahteraan (walfare) di dalamnya saling paling tidak mengandung tiga subsklasifikasi, yakni : (1) social welfare, yang mengacu kepada penerimaan kolektif kesejahteraan, (2) economic welfare, yang mengacu kepada jaminan keamanan melalui pasar atau ekonomi formal; dan (3) state welfare, yang mengacu kepada jaminan pelayanan kesejahteraan sosial melalui agen dari negara. Negara Kesejahteraan (welfare state) secara singkat mendefinisikan sebagai suatu negara dimana pemerintahan Negara dianggap bertanggung jawab dalam menjamin standar kesejahteraan hidup minimum bagi setiap warga negaranya.

Indonesia sebagai negara hukum modern (welfare state) dalam rangka mewujudkan tujuan negara yakni memberikan kesejahteraan bagi masyarakatnya dan melindungi hak-hak warga negaranya, harus menganut prinsip utama atau asas pokok yang terdiri atas legalitas, asas pengakuan dan perlindungan hak asasi manusia, asas pembagian kekuasaan negara, asas peradilan yang bebas dan tidak memihak, asas kedaulatan rakyat, asas demokrasi dan asas konstitusional.

Untuk memahami pengertian welfare state (kesejahteraan negara), maka perlu kita membahas terlebih dahulu mengenai konsep kesejahteraan (welfare) yang sering diartikan berbeda oleh setiap orang dan setiap negara yang tentu saja berbeda pula. Berdasarkan Kamus Bahasa Indonesia, kesejahteraan berarti hal atau keadaan sejahtera, keamanan, keselamatan dan ketenteraman. Secara semantis, kata ini memiliki kemiripan makna dengan kemakmuran, kesentosaan, keselamatan, keamanan, kesenangan, dan kedamaian.

Kesejahteraan atau sejahtera dapat memiliki 4 (empat) arti. Pertama, dalam istilah umum sejahtera menunjuk ke keadaan yang baik, kondisi manusia dimana orangorangnya dalam keadaan makmur, sehat dan damai. Kedua, dalam ekonomi, sejahtera dihubungkan dengan keuntungan benda. Sejahtera memiliki arti khusus resmi atau teknikal seperti dalam istilah fungsi kesejahteraan sosial. Ketiga, dalam kebijakan sosial, kesejahteraan sosial menunjuk ke jangkauan pelayanan untuk memenuhi kebutuham 
masyarakat. Ini adalah istilah yang digunakan dalam ide negara sejahtera.

Kesejahteraan negara ditujukan untuk menyediakan pelayanan-pelayanan sosial bagi seluruh penduduk, orang tua, dan anak-anak, pria, dan wanita, kaya, miskin, sebaik dan sependapat mungkin. la berupaya untuk mengintegrasikan sistem sumber dan menyelenggarakan jaringan pelayanan yang dapat memelihara dan meningkatkan kesejahteraan (wel-being) warga negara secara adil dan berkelanjutan.

Negara kesejahteraan sangat erat kaitannya dengan kebijakan sosial (social policy) yang di banyak negara mencakup strategi dan upaya-upaya pemerintah dalam meningkatkan kesejahteraan warganya, terutama melalui perlindungan sosial (social protection) yang mencakup jaminan sosial, baik berbentuk bantuan sosial dan asuransi sosial maupun jarring pengaman sosial (social safety nets)

Konsep kesejahteraan negara tidak hanya mencakup deskripsi mengenai sebuah cara pengorganisasian kesejahteraan (welfare) atau pelayanan sosial (social services). Namun, di dalamnya terkandung juga sebuah konsep normatif atau system pendekatan ideal yang menekankan bahwa setiap orang harus memperoleh pelayanan sosial sebagai haknya.

Bahwa menurut peneliti perlindungan hukum bisnis terhadap perempuan pekerja pembuat atap di Desa Amokuni Kecamatan Ranomeeto Barat Kabupaten Konawe Selatan bukan hanya sekedar dari hubungan antara perempuan pembuat atap dengan pembeli atap dalam sebuah perjanjian jual beli, tetapi peran pemerintah harusnya dapat turun langsung melalui aparat pemerintah desa dengan melakukan perlindungan dengan cara membuat kelompok-kelompok tani/usaha, sehingga haknya dapat maksimal diberikan perlindungan oleh hukum. Apakah itu mengenai Kesehatan dan Keselamatan Kerja (K3), asuransi sosial, maupun keberlangsungan dari usaha serta kearifan lokal dapat tumbuh dan terjaga di desa tersebut.

\section{Faktor-Faktor Yang Mempengaruhi Perlindungan Hukum Terhadap Perempuan Pekerja Atap di Desa Amokuni Kecamatan Ranomeeto Barat Kabupaten Konawe Selatan}

Peranan wanita dalam aktivitas rumah tangga berarti wanita sebagai ibu rumah tangga. Dalam hal ini wanita memberikan peran yang sangat penting bagi pembentukan keluarga sejahtera sebagai unit terkecil dalam kehidupan bermasyarakat, berbangsa, dan bernegara. Kehidupan yang sehat sejahtera harus dapat dimanifestasikan dalam kehidupan sehari-hari. Menurut Kuswardinah (2007:134) untuk menciptakan suatu keluarga yang baik perlu didukung hal sebagai berikut :

1. Kesehatan jasmani harus diperhatikan, mulai dari kesehatan suami, istri dan kesehatan anak sejak dalam kandungan, usia balita, hingga dewasa, gizi keluarga, hidup bersih serta teratur.

2. Kesehatan rohani harus diperhatikan, mulai dari sikap perilaku orang tua sejak anak masih dalam kandungan, mengajarkan pendidikan moral, sosial, dan agama dalam keluarga, sera menjadi tauladan bagi anak-anaknya.

3. Ekonomi keluarga yang dapat menunjang kehidupan rumah tangga, yaitu adanya keseimbangan antara penghasilan dan pengeluaran, menentukan skala prioritas, menambah pendapatan keluarga dengan kesempatan wanita sebagai ibu runah tangga yang bekerja atau berwiraswasta. 
Wanita sebagai bagian dari keluarga mempunyai tugas-tugas antara lain sebagai istri, sebagai ibu rumah tangga, sebagai pendidik bagi anak-anaknya. Menurut Hemas (dalam Pudjiwati, 1997:35) memaparkan bahwa tugas yang disandang oleh seorang wanita, yaitu :

1. Wanita sebagai Istri

Wanita tidak hanya sebagai ibu rumah tangga tetapi juga sebagai pendamping suami seperti sebelum menikah, sehingga dala rumah tangga tetap terjalin ketentraman yang dilandasi kasih sayang yang sejati. Wanita sebagai istri dituntut untuk setia pada suami agar dapat menjadi motivator kegiatan suami.

2. Wanita sebagai ibu rumah tangga

Sebagai ibu rumah tangga yang bertanggung jawab secara terus-menerus memperhatikan kesehatan rumah dan tata laksana rumah tangga, mengatur segala sesuatu di dalam rumah tangga untuk meningkatkan mutu hidup. Keadaan rumah harus mencerminkan rasa nyaman, aman tentram, dan damai bagi seluruh anggota keluarga

3. Wanita sebagai pendidik

Ibu adalah wanita pendidik pertama dan utama dalam keluarga bagi putra-putrinya. Menanamkan rasa hormat, cinta kasih kepada Tuhan Yang Maha Esa serta kepada masyarakat dan orang tua. Pada lingkungan keluarga, peran ibu sangat menentukan perkembangan anak yang tumbuh menjadi dewasa sebagai warga Negara yang berkualitas dan pandai.

Berdasarkan hasil wawancara tanggal 15 Maret 2017 dengan bapak Muhtar selaku Sekretaris Desa Amokuni Kecamatan Ranomeeto Barat Kabupaten Konawe Selatan, mengatakan bahwa: faktor-faktor yang mempengaruhi perlindungan hukum terhadap perempuan pekerja atap adalah faktor eksternal dan internal. Faktor eksternal adalah kurangnya peran pemerintah dalam melindungi perempuan pekerja atap dengan memberikan kesehatan dan keselamatan kerja (K3) dalam bekerja. Sedangkan faktor internal adalah tidak adanya support/dukungan dari suami, hal ini terlihat dengan menjadikannya pembuatan atap sebagai penopang/pekerjaan tetap dalam suatu keluarga.

Selanjutnya, bapak Harun selaku Ketua LPM Desa Amokuni, mengatakan bahwa: seharusnya pemerintah menjamin perlindungan hukum terhadap perempuan pekerja atap yang meliputi $\mathrm{K} 3$, asuransi, serta pengadaan pelatihan-pelatihan dalam bidang hukum bisnis, pembentukan koperasi dan manajemen, sehingga hasil dari pembuatan atap dapat meningkat tidak hanya dari segi kualitasnya tetapi juga kuantitasnya. (Wawancara tanggal 15 Maret 2017)

Dari hasil penelitian penulis, faktor-faktor yang mempengaruhi perlindungan hukum terhadap perempuan pekerja atap di Desa Amokuni Kecamatan Ranomeeto Barat Kabupaten Konawe Selatan adalah kurangnya kesadaran perempuan tentang pentingnya Kesehatan dan Keselamatan Kerja (K3) dalam membuat atap, tidak adanya pelatihan yang diberikan pemerintah tentang usaha untuk membentuk kelompok pekerja/koperasi kepada perempuan pembuat atap serta daya saing kualitas dan kuantitas tidak mencirikan kearifan lokal dari Desa Amokuni. 


\section{KESIMPULAN}

Perlindungan hukum bisnis terhadap perempuan pekerja pembuat atap di Desa Amokuni Kecamatan Ranomeeto Barat Kabupaten Konawe Selatan bukan hanya sekedar dari hubungan antara perempuan pembuat atap dengan pembeli atap dalam sebuah perjanjian jual beli, tetapi peran pemerintah harusnya dapat turun langsung melalui aparat pemerintah desa dengan melakukan perlindungan dengan cara membuat kelompok-kelompok tani/usaha, sehingga haknya dapat maksimal diberikan perlindungan oleh hukum. Apakah itu mengenai Kesehatan dan Keselamatan Kerja (K3), asuransi sosial, maupun keberlangsungan dari usaha serta kearifan lokal dapat tumbuh dan terjaga di desa tersebut. Faktor-faktor yang mempengaruhi perlindungan hukum terhadap perempuan pekerja atap di Desa Amokuni Kecamatan Ranomeeto Barat Kabupaten Konawe Selatan adalah kurangnya kesadaran perempuan tentang pentingnya Kesehatan dan Keselamatan Kerja (K3) dalam membuat atap, tidak adanya pelatihan yang diberikan pemerintah tentang usaha untuk membentuk kelompok pekerja/koperasi kepada perempuan pembuat atap serta daya saing kualitas dan kuantitas tidak mencirikan kearifan lokal dari Desa Amokuni. Rekomendasi yang peneliti berikan berupa: 1).Pemerintah daerah melalui kepala desa Amokuni, dapat mengakomodir perempuan pembuat atap untuk dibentuk kelompok tani/usaha yang berbadan hukum. 2).Perempuan pembuat atap dapat meningkatkan kualitas dan kuantitas dalam menghasilkan lembaran atap sehingga kekhasan daerah dan kearifan lokalnya dapat terjaga.

\section{UCAPAN TERIMA KASIH}

Penulis mengucapkan terima kasih kepada Lembaga Penelitian dan Pengabdian Kepada Masyarakat (LPPM), Universitas Muhammadiyah Kendari yang telah memberikan dukungan finansial dalam penelitian ini.

\section{DAFTAR PUSTAKA}

Abdul Kadir Muhammad. (2008). Hukum Pengangkutan Niaga. Bandung: Citra Aditya Bakti.

Ali Mansyur. (2007). Penegakah Hukum tentang Tanggung Gugat Produsen Dalam Perwujudan Perlindungan Konsumen. Yogyakarta: Genta Press.

Ayatullah Khomeini. (2004). Kedudukan Wanita. Jakarta: Pustaka Lentera.

Departemen Pendidikan Nasional (2012). Kamus Besar Bahasa Indonesia, Pusat Bahasa (Edisi Keempat). Jakarta: PT.Gramedia Pustaka Utama.

Janus Sidabolak. (2007). Hukum Perlindungan Konsumen. Bandung: Citra Aditya Bakti.

Munir Fuadi. (2008). Hukum Bisnis Dalam Teori dan Praktek Buku II, Bandung: Citra Aditya Bakti.

Ridwan Khairanduy. (2006). Tanggung Jawab Pengangkut dan Asuransi Tanggung Jawab Sebagai Instrument Perlindungan Konsumen Angkutan Udara, Jurnal Hukum Bisnis Vol.25, Jakarta.

Zaini Noer dan Usman Melayu. (2002). Kebijakan Transportasi. Jakarta: Simposium III FSTPT. 


\section{Perundang-Undangan}

Undang-Undang Nomor 1 Tahun 1995 sebagaimana telah diubah menjadi UndangUndang nomor 40 tahun 2007 tentang Perseoran Terbatas.

Undang-Undang Nomor 25 Tahun 1992 tentang Perkoperasian.

Undang-Undang Nomor 14 Tahun 2001 sebagaimana telah diubah menjadi UndangUndang Nomor 13 tahun 2016 tentang Paten.

Undang-Undang Nomor 15 Tahun 2001 sebagaimana telah diubah menjadi UndangUndang Nomor 20 tahun 2016 tentang Merek dan Indikasi Geografis.

Undang-Undang Nomor 30 Tahun 2000 tentang Rahasia Dagang.

Undang-Undang Nomor 31 Tahun 2000 tentang Desain Industri.

Undang-Undang Nomor 5 Tahun 1999 tentang Larangan Monopoli dan Persaingan Usaha Tidak Sehat.

Undang-Undang Nomor 8 Tahun 1999 tentang Perlindungan Konsumen.

\section{Internet :}

http://www.slideshare.net/ZsazsaDhyshal/materi-hukumbisnis1 http://frymaruwah.blogspot.com/2010/10/hukum-bisnis.html http://statushukum.com/hukum-bisnis-Indonesia.html 